\title{
Technical Note: Assessment of Recovery Site of Mobile Nylon Bags for Measuring Ileal Digestibility of Starch in Dairy Cows
}

\author{
E. Norberg, ${ }^{*}$ H. Volden, $\dagger$ and O. M. Harstad $\dagger^{1}$ \\ *Department of Genetics and Biotechnology, Danish Institute of Agricultural Sciences, Research Centre Foulum, Tjele, Denmark \\ †Department of Animal and Aquacultural Sciences, University of Life Sciences, Ås, Norway
}

\begin{abstract}
The objective of this study was to evaluate recovery site of mobile nylon bags for measuring ileal digestibility of ruminally undegraded starch in dairy cows. Eight feed samples of untreated and treated concentrates were examined. Three lactating cows equipped with rumen fistula and duodenal and ileal cannulas were used in the experiment. The mobile nylon bags containing intact feeds or residues after a 12-h ruminal incubation were pretreated using a 2 -step procedure to simulate abomasal digestion before insertion through the duodenal cannula. To assess the effect of hindgut fermentation on starch digestibility, approximately half of the bags were collected from the ileum and half from the feces. The results indicate that feed samples should be preincubated in rumen before insertion into duodenum, and that samples with relatively high fractions of rumenundigestible starch should be collected from the ileum instead of from feces.
\end{abstract}

Key words: dairy cow, starch, intestinal digestibility, mobile nylon bag technique

Starch is the major component of cereal grains and is therefore a significant source of energy in diets for highproducing dairy cows. Starch escaping ruminal degradation is subject to enzymatic digestion in the small intestine and absorbed as glucose. A shift of starch digestion from the rumen to the small intestine may increase the net energy value of the feed (Nocek and Tamminga, 1991). Moreover, it has been suggested that increasing the supply of intestinally digestible starch to the small intestine may spare AA from deamination in the intestinal wall and by the liver, and thereby increase the supply of AA to the mammary gland. This may increase milk yield and protein production, although reported results are inconclusive (Nocek and Tamminga, 1991; Reynolds et al., 2001; Volden and Harstad, 2002; Rulquin et al., 2004). True intestinal digestibility of starch varies be-

Received October 14, 2005.

Accepted July 28, 2006.

${ }^{1}$ Corresponding author: odd.harstad@umb.no tween feedstuffs, and the site and extent of digestion may be influenced by physical treatment (Mills et al., 1999; Svihus et al., 2005). Starch leaving the small intestine will be subjected to microbial fermentation in the hindgut (Mills et al., 1999). Thus, starch digestibility measured as the difference between starch reaching the small intestine and starch excreted in feces may not reflect the amount of starch truly absorbed in the small intestine.

Determination of ileal starch digestibility requires animals fitted with cannulas in the duodenum and the ileum. However, such in vivo experiments are time consuming and expensive. Therefore, an alternative method to measure ileal starch digestibility would be highly appreciated. A possible method may be the mobile nylon bag (MNB) technique (Madsen et al., 1995). Traditionally, this method is based on disappearance of material from nylon bags inserted in the duodenum and collected in feces. The method may therefore overestimate small intestine digestibility due to microbial degradation of starch in the hindgut. Consequently, collecting nylon bags from the ileum instead of from feces may provide a truer estimation of starch ileal digestibility. But the use of this method, in which nylon bags are recovered in ileum, has some disadvantages because it is labor intensive and requires more extensive surgical intervention. Therefore, the objective of this study was to evaluate the effect of recovery site of MNB used to determine ileal starch digestibility.

Three lactating dairy cows of the Norwegian Cattle breed, 80 to 90 DIM and with an average daily milk yield of $31 \mathrm{~kg}$, were used in the experiment. The animals were fitted with a rumen fistula, a closed T-shaped cannula located in duodenum 50 to $60 \mathrm{~cm}$ distal to the pylorus and an open T-shaped cannula located in the ileum 50 to $60 \mathrm{~cm}$ proximal to the ileo-cecal junction. The diet consisted of $9 \mathrm{~kg}$ of DM/d of grass silage $(97 \mathrm{~g}$ of CP, $66 \mathrm{~g}$ of ash, $20 \mathrm{~g}$ of fat, and $573 \mathrm{~g}$ of NDF/ $\mathrm{kg}$ of $\mathrm{DM})$ and $13 \mathrm{~kg} / \mathrm{d}$ of a commercial expander-treated (110 to $120^{\circ} \mathrm{C}$ ) concentrate mixture with barley, oats, and wheat bran as the main ingredients ( $193 \mathrm{~g}$ of CP, $70 \mathrm{~g}$ of ash, $68 \mathrm{~g}$ of fat, $281 \mathrm{~g}$ of NDF, and $297 \mathrm{~g}$ of starch/kg of DM). This ration was offered in 4 equal meals at 0600 , 1200,1800 , and $2400 \mathrm{~h}$. The daily intake of starch was 
Table 1. Experimental feedstuffs and their content of DM, ash, fat, CP, ADF, NDF, and starch

\begin{tabular}{|c|c|c|c|c|c|c|c|c|}
\hline $\begin{array}{l}\text { Feedstuff } \\
\text { no. }\end{array}$ & Experimental feedstuff & $\mathrm{DM}$ & Ash & Fat & $\mathrm{CP}$ & $\mathrm{ADF}$ & NDF & Starch \\
\hline & & $(\%)$ & - & 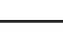 & $-(\%$ & of $\mathrm{DM})$ & $\longrightarrow$ & \\
\hline 1 & Barley meal, untreated & 88.5 & 1.9 & 2.4 & 12.6 & 3.8 & 20.3 & 62.1 \\
\hline 2 & Barley, toasted $100^{\circ} \mathrm{C}, 3 \mathrm{~min}$ & 90.7 & 2.0 & 2.3 & 12.7 & 3.7 & 20.5 & 62.3 \\
\hline 3 & Barley, toasted $118^{\circ} \mathrm{C}, 1.5 \mathrm{~min}$ & 90.7 & 1.9 & 2.3 & 12.4 & 3.7 & 19.9 & 64.9 \\
\hline 4 & Oats meal, untreated & 90.4 & 2.7 & 5.1 & 11.6 & 12.5 & 33.6 & 45.8 \\
\hline 5 & Oats, toasted $136^{\circ} \mathrm{C}, 1.5 \mathrm{~min}$ & 90.2 & 2.4 & 4.7 & 12.2 & 9.6 & 27.7 & 47.1 \\
\hline 6 & Barley and oat-based concentrate ${ }^{1}$ & 89.5 & 6.3 & 6.4 & 18.0 & 8.5 & 25.4 & 34.5 \\
\hline 7 & Barley, oat, and corn-based concentrate ${ }^{1,2}$ & 88.7 & 5.9 & 6.2 & 18.0 & 7.7 & 22.9 & 38.4 \\
\hline 8 & Barley, oat, and corn-based concentrate ${ }^{1,3}$ & 88.4 & 7.1 & 6.0 & 18.9 & 6.6 & 19.7 & 38.7 \\
\hline 9 & Barley-based concentrate, pelleted & 87.6 & 7.4 & 3.9 & 17.6 & 5.7 & 19.4 & 44.5 \\
\hline 10 & Barley-based concentrate, expanded ${ }^{4}$ & 90.0 & 5.6 & 4.4 & 17.4 & 4.9 & 17.2 & 46.3 \\
\hline
\end{tabular}

approximately $3.5 \mathrm{~kg}$, and, based on earlier results with comparable diets, approximately $560 \mathrm{~g} / \mathrm{d}$ of starch reached the small intestine (Volden, 1999; Prestløkken and Harstad, 2001; Harstad et al., 2002). The study comprised 10 feedstuffs with chemical composition and treatments given in Table 1.

The in situ procedure was used to obtain residues of starch resistant to rumen degradation for the MNB experiment (Madsen et al., 1995). All feedstuffs were ground through a 1.6-mm screen. Thereafter, $2 \mathrm{~g}$ of each feedstuff (in 8 replicates) was placed in an artificial fiber bag $(6 \times 12 \mathrm{~cm})$ with pore a size of $36 \mu \mathrm{m}(\mathrm{ZBF}, \mathrm{AG}$, Rüschlicon, Switzerland). All bags were placed in the rumen for $12 \mathrm{~h}$. Immediately after removal from the rumen, bags were rinsed in cold tap water and washed for $3 \times 10 \mathrm{~min}$, and centrifuged in a domestic washing machine. The bags were then dried at $45^{\circ} \mathrm{C}$ for $48 \mathrm{~h}$ and equilibrated for $24 \mathrm{~h}$ before being weighed. Residues of the replicates were pooled within feedstuff and animal. A representative sample of the residue was ground for 1 min in a mixer mill (Retsch 2000 MM, Haan, Germany), and stored at room temperature in airtight glass tubes until analyzed for starch. The remaining residues were stored in airtight glass jars until used in the MNB experiment. Particle loss through the pores of the nylon bags in the rumen was not determined.

The MNB technique described by Volden and Harstad (1995) with some modifications was used to determine intestinal starch digestibility of ruminal preincubated samples and intact feeds. Bag size was reduced from 6 $\times 6$ to $4 \times 4 \mathrm{~cm}$, and the sample size from 1,000 to 500 $\mathrm{mg}$ for intact feed and from 500 to $250 \mathrm{mg}$ for the samples preincubated in the rumen. The bags had a pore size of $15 \mu \mathrm{m}$ and were closed by heat sealing. To be able to recover the bags from the ileum, a piece of metal of approximately $0.4 \mathrm{~g}$ was placed in the bags along with the sample (Jarosz et al., 1991; Prestløkken and Rise, 2003). For each experimental feed and animal, 12 bags with intact feed and 6 bags with residues after ruminal incubation were prepared. The samples were pretreated applying a 2-step procedure to simulate abomasal digestion (Volden and Harstad, 1995) and then inserted through the duodenal cannula at a rate of 4 bags every $45 \mathrm{~min}$. However, additional bags were not inserted before the previous bags had left the cannula. A strong cylindrical magnet $(1.0 \mathrm{~cm}$ in diameter and $4 \mathrm{~cm} \mathrm{long})$ connected to the ileal cannula plug was used to collect bags from the ileum. The ileal cannula was inspected every 20 min for bags captured by the magnet starting $2 \mathrm{~h}$ after the first bags were inserted in the duodenum. When half of the bags had been recovered, the magnet was removed, and the rest of the bags were collected from the feces. The replicates were pooled within feedstuff, animal, preincubation, and recovery site. Bags that spent more than $24 \mathrm{~h}$ in the intestinal tract were omitted from statistical analyses.

Contents of DM, ash, fat (acid hydrolysis and extraction with petroleum ether), and nitrogen in the experimental feedstuffs were determined by standard procedures as described by AOAC (1990). Crude protein was calculated as $\mathrm{N} \times 6.25$. Acid detergent fiber and NDF were determined according to Goering and Van Soest (1970). Starch content in the experimental feedstuffs and residues after ruminal and intestinal incubation was determined as described by McCleary et al. (1994) without correction for glucose.

Rumen degradability of starch (RDS) was calculated from the disappearance of starch from the bags after $12 \mathrm{~h}$ of rumen incubation. The indigestible starch (IS) fraction was calculated according to equation [1] for intact feed and equation [2] for feed residues after $12 \mathrm{~h}$ of rumen incubation: 
Table 2. Ruminal degradation of starch after $12 \mathrm{~h}$ incubation (RDS) and indigestible fraction of starch measured in intact feed (IF) and samples preincubated in the rumen for $12 \mathrm{~h}$ (12RI), inserted in duodenum and recovered in ileum and feces

\begin{tabular}{|c|c|c|c|c|c|c|c|c|c|c|c|}
\hline \multirow[b]{2}{*}{ Feedstuff no. } & \multirow{2}{*}{$\frac{\mathrm{RDS}}{12 \mathrm{~h}}$} & \multicolumn{2}{|c|}{ Ileum } & \multicolumn{2}{|c|}{ Feces } & \multirow[b]{2}{*}{$\mathrm{SE}$} & \multicolumn{5}{|c|}{ Contrast $^{1}$} \\
\hline & & IF & $12 \mathrm{RI}$ & IF & $12 \mathrm{RI}$ & & 1 & 2 & 3 & 4 & 5 \\
\hline & & $-(\%$ & intact & d) & - & & & & & & \\
\hline 1 & 99.2 & 15.01 & 0.06 & 2.90 & 0.04 & 0.55 & $* *$ & $* *$ & $* *$ & NS & $* *$ \\
\hline 2 & 94.9 & 13.91 & 0.07 & 3.40 & 0.05 & 0.79 & $* *$ & $* *$ & $* *$ & NS & $*$ \\
\hline 3 & 94.0 & 12.69 & 0.07 & 4.65 & 0.09 & 0.42 & $* *$ & $* *$ & $* *$ & NS & $* *$ \\
\hline 4 & 99.5 & 0.17 & 0.05 & 0.10 & 0.04 & 0.02 & NS & NS & NS & NS & NS \\
\hline 5 & 98.9 & 0.19 & 0.10 & 0.09 & 0.08 & 0.04 & NS & NS & NS & NS & NS \\
\hline 6 & 98.3 & 2.48 & 0.06 & 0.27 & 0.06 & 0.18 & $*$ & NS & $*$ & NS & $*$ \\
\hline 7 & 87.6 & 8.42 & 1.02 & 4.31 & 0.75 & 0.49 & $* *$ & $* *$ & $* *$ & $* *$ & $*$ \\
\hline 8 & 78.1 & 12.99 & 1.31 & 9.15 & 0.90 & 0.65 & $* *$ & $* *$ & $* *$ & $* * *$ & NS \\
\hline 9 & 99.1 & 12.06 & 0.07 & 1.29 & 0.05 & 0.27 & $* *$ & * & $* *$ & NS & $* *$ \\
\hline 10 & 97.9 & 6.11 & 0.08 & 0.63 & 0.03 & 0.18 & $* *$ & NS & $* *$ & NS & $* *$ \\
\hline
\end{tabular}

${ }^{1}$ Contrasts: 1 = intact feed vs. ruminal preincubated feed recovered in ileum; $2=$ intact feed vs. ruminal preincubated feed recovered in feces; $3=$ intact feed recovered in ileum vs. feces; $4=$ ruminal preincubated feed recovered in ileum vs. feces; $5=$ recovery site $\times$ pretreatment interaction.

$\mathrm{NS}=P>0.1 ; *=0.05>P>0.01 ; * *=P<0.01$.

$$
\begin{gathered}
\mathrm{IS}=100-\mathrm{DS} \\
\mathrm{IS}=(100-\mathrm{DS}) \times(100-\mathrm{RDS}) / 100
\end{gathered}
$$

where IS = indigestible fraction of starch (\% of starch in intact feed); DS = digestible fraction of starch in the small, or small and large intestine (\% of starch in intact feed); and RDS = loss of starch after $12 \mathrm{~h}$ ruminal incubation (\% of starch in intact feed).

The PROC GLM procedure in SAS (SAS Institute, Inc., Cary, NC) was used for the statistical analysis. The following model was used:

$$
\mathrm{Y}_{\mathrm{ijkl}}=\mu+\alpha_{\mathrm{i}}+\beta_{\mathrm{j}}+\delta_{\mathrm{k}}+\eta_{\mathrm{l}}+(\delta \times \eta)_{\mathrm{kl}}+\varepsilon_{\mathrm{ijkl}}
$$

where $Y_{\mathrm{ijkl}}=$ indigestible fraction of starch; $\mu$ = mean; $\alpha_{\mathrm{i}}=$ fixed effect of animal $(\mathrm{i}=1,2,3) ; \beta_{\mathrm{j}}=$ fixed effect of feedstuff $(\mathrm{j}=1,2, \ldots .9,10) ; \delta_{\mathrm{k}}=$ fixed effect of ruminal incubation $(\mathrm{k}=1,2) ; \eta_{1}=$ fixed effect of recovery site $(\mathrm{l}=$ $1,2) ;(\delta \times \eta)_{\mathrm{kl}}=$ interaction between ruminal incubation and recovery site; and $\varepsilon_{\mathrm{ijkl}}=$ random residual.

Orthogonal contrasts were used to separate the means of different effects. The significance level was set to $P<$ 0.05 and $P$-values between 0.05 and 0.1 were considered to reflect trends.

Ruminal disappearance of starch after a 12-h incubation is presented in Table 2. Values were relatively high for most of the feedstuffs except for the concentrate mixture containing 12.5 and $25 \%$ corn (feedstuffs 7 and 8 ). However, disappearance of starch through the bag pores without being degraded may also result in overestimation of rumen starch degradability. The in situ method, which measures the disappearance of material from the nylon bags, ignores the fact that the capacity to digest starch and absorb glucose may be limited in vivo (Mills et al., 1999; Harmon et al., 2004). Consequently, the MNB technique may overestimate starch digestibility and absorption. Huntington (1994) suggested that the upper limit for starch digestion in the small intestine is $1,300 \mathrm{~g} / \mathrm{d}$. In our study, approximately $560 \mathrm{~g} / \mathrm{d}$ reached the small intestine. Thus, it is unlikely that starch digestion in the small intestine was depressed in the present experiment.

An important factor affecting the disappearance of material from the MNB is the retention time of the bags in the intestine (Vanhatalo and Ketoja, 1995). Prestløkken and Rise (2003) used a 0.7-g metallic slice in a comparable study. They observed that the intestinal retention time of the bags was significantly longer for bags containing a metallic slice compared with bags without a metal slice. In the present study, the effect of the metallic slice on the retention time was probably less, because the metallic slice was only $0.4 \mathrm{~g}$ (i.e., 0.3 $\mathrm{g}$ lighter than that used in the experiment of Prestløkken and Rise, 2003).

Mean values of IS for both intact feeds and ruminally preincubated feeds from bags recovered in ileum and feces are shown in Table 2. Except for oats (feedstuffs 4 and 5), IS was higher in intact feed than in ruminal preincubated feeds when nylon bags were recovered from the ileum. These results indicate that exposure to microbial digestion in the rumen may increase the availability of rumen undegraded starch for enzymatic digestion in the small intestine. In barley, a protein matrix surrounds the starch granules (Hoseney, 1994) and ruminal preincubation increases intestinal digestibility of barley protein (Volden and Harstad, 1995). Thus, ruminal preincubation promotes digestion of the protein matrix and 
exposes the starch granules to enzymatic digestion in the small intestine. When the bags were collected in feces, only the concentrate mixtures that contained 12.5 and $25 \%$ corn and were high in ruminally resistant starch (feedstuffs 7 and 8) showed a difference in IS between intact feed and preincubated feeds. These results agree with previous research demonstrating that depressed starch digestion in the small intestine is, to a great extent, compensated for by digestion in the large intestine (Mills et al., 1999).

In vivo, feed particles escape from the rumen continuously. Ideally, the length of ruminal preincubation for the bags should be equal to the time required to obtain ruminal degradation equivalent to that measured in vivo. For ruminal preincubated feedstuffs, only the concentrate mixtures high in ruminally resistant starch (feedstuffs 7 and 8) showed a significant effect of recovery site on IS. For the other feedstuffs, the fraction of IS after passage through the small intestine was so small that recovery site had practically no effect on the measurements of indigestibility. For barley and the barleybased concentrate mixture there were interactions between pretreatment and recovery site. The recovery site showed a significant effect on the fraction of IS for intact samples, whereas no such effect was observed for the corresponding samples preincubated in the rumen. This result underlines, as already discussed, the promoting effect of microbes on digestion of the protein matrix, which exposes the starch granules to enzymatic digestion.

Our results indicate that in situ measurements should be performed on ruminally preincubated samples and that feed samples with relatively high ruminally resistant starch should be collected from the ileum instead of from feces. For feedstuffs with a low fraction of ruminally resistant starch, no effect of nylon bag recovery site was found. Therefore, for most feedstuffs, small intestinal digestibility of dietary starch can be obtained by recovering the bags from the feces.

\section{ACKNOWLEDGMENTS}

The authors thank E. Prestløkken and 2 anonymous reviewers for valuable comments on the manuscript, $\mathrm{K}$. Hove for surgery of experimental animals, I. J. Jørgensen for performing the starch analysis, and R. Øvstegård, M. Henne, J. Alne, and A. Kvernsveen for animal caretaking and technical assistance.

\section{REFERENCES}

AOAC. 1990. Official Methods of Analysis. 15th ed. Association of Official Analytical Chemists, Gaithersburg, MD.
Goering, H. K., and P. J. Van Soest. 1970. Forage fiber analysis. Agriculture Handbook 379, USDA, Washington, DC.

Harmon, D. L., R. M. Yamka, and N. A. Elam. 2004. Factors affecting intestinal starch digestion in ruminants: A review. Can. J. Anim. Sci. 84:309-318.

Harstad, O. M., E. Norberg, J. O. Goelema, and S. Tamminga. 2002. Effects of pressure toasting of barley on ruminal fermentation, amount of metabolizable starch and protein, and performance of dairy cows. Page 53 in Proc. 53rd Annu. Mtg. EAAP, Cairo, Egypt. Wageningen Acad. Publ., Wageningen, the Netherlands.

Hoseney, R. C. 1994. Principles of Cereal Science and Technology. American Association of Cereal Chemists, Inc., St. Paul, MN.

Huntington, G. B. 1994. Ruminant starch utilization progress has been extensive. Feedstuffs June 6:18-43.

Jarosz, L., M. R. Weisbjerg, T. Hvelplund, and B. Borg Jensen. 1991. Digestibility of nitrogen and $15 \mathrm{~N}$ from different roughages in the lower gut of cows estimated with the mobile nylon bag procedure. Proc. 6th Int. Symp. Protein Metabolism and Nutrition, Herning, Denmark. Natl. Inst. Anim. Sci., Tjele, Denmark.

Madsen, J., T. Hvelplund, M. R. Weisbjerg, J. Bertilsson, I. Olsson, R. Spörndly, O. M. Harstad, H. Volden, M. Tuori, T. Varvikko, P. Huhtanen, and B. L. Olafsson. 1995. The AAT/PBV protein evaluation system for ruminants. A revision. Norwegian J. Agric. Sci. (Suppl. 19):1-37.

McCleary, B. V., V. Solah, and T. S. Gibson. 1994. Quantitative measurement of total starch in cereal flours and products. J. Cereal Sci. 20:51-58.

Mills, J. A. N., J. France, and J. Dijkstra. 1999. A review of starch digestion in the lactating dairy cows and proposals for a mechanistic model: 2. Postruminal starch digestion and small intestinal glucose absorption. J. Anim. Feed Sci. 8:451-481.

Nocek, J. E., and S. Tamminga. 1991. Site of digestion of starch in the gastrointestinal tract of dairy cows and its effect on milk yield and composition. J. Dairy Sci. 74:3598-3629.

Prestløkken, E., and O. M. Harstad. 2001. Effects of expander-treating a barley based concentrate on ruminal fermentation, bacterial $\mathrm{N}$ synthesis, escape of dietary $\mathrm{N}$, and performance of dairy cows. Anim. Feed Sci. Technol. 90:227-246.

Prestløkken, E., and O. Rise. 2003. Protein and amino acid digestibility in dairy cows measured with mobile nylon bag recovered in ileum or faeces. Acta Agric. Scand. A, Anim. Sci. 53:11-20.

Reynolds, C. K., S. B. Cammell, D. J. Humphries, D. E. Beever, J. D. Sutton, and J. R. Newbold. 2001. Effect of postrumen starch infusion on milk production and energy metabolism in dairy cows. J. Dairy Sci. 84:2250-2259.

Rulquin, H., S. Rigout, S. Lemosquet, and A. Bach. 2004. Infusion of glucose directs circulating amino acids to the mammary gland in well-fed cows. J. Dairy Sci. 87:340-349.

Svihus, B., A. K. Uhlen, and O. M. Harstad. 2005. Effect of starch granule structure, associated components and processing on nutritive value of cereal starch: A review. Anim. Feed Sci. Technol. 122:303-320.

Vanhatalo, A., and E. Ketoja. 1995. The role of the large intestine in post-ruminal digestion of feeds measured by the mobile-bag method in cattle. Br. J. Nutr. 73:491-505.

Volden, H. 1999. Effect of level of feeding and ruminally undegraded protein on ruminal bacterial protein synthesis, escape of dietary protein, intestinal amino acid profile and performance of dairy cows. J. Anim. Sci. 77:1905-1918.

Volden, H., and O. M. Harstad. 1995. Effect of rumen incubation on the true indigestibility of feed protein in the digestive tract determined by nylon bag techniques. Acta Agric. Scand. A, Anim. Sci. 45:106-115.

Volden, H., and O. M. Harstad. 2002. Effects of duodenal amino acid and starch infusion on milk production and nitrogen balance in dairy cows. J. Anim. Sci. 80(Suppl. 1):321. (Abstr.) 